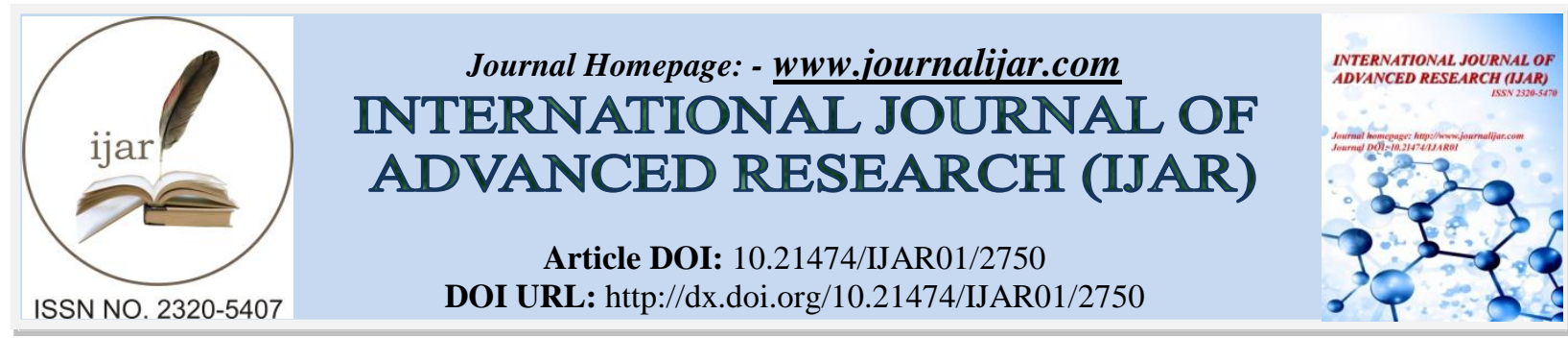

RESEARCH ARTICLE

\title{
Phytochemical screening and Antimicrobial activity of Euphorbia linearifolia var.nallamalayana J.L.Ellis from the Nucleus of Eastern Ghats.
}

D.Nirmala Grace ${ }^{1}$ and Z.Vishnu Vardhan ${ }^{2}$.

1. Department of Botany and Microbiology, Nagarjuna University, Guntur, Andhra Pradesh, India.

2. Department of Botany and Microbiology, Acharya Nagarjuna University Guntur, Andhra Pradesh, India.

\section{Manuscript Info}

Manuscript History

Received: 15 November 2016

Final Accepted: 17 December 2016

Published: January 2017

Key words:-

Euphorbia nallamalayana, Endemic, Antibacterial, Antifungal, Agar well diffusion, Phytochemical Screening.

\section{Abstract}

The current study was focused to investigate the phytochemical analysis, antibacterial and antifungal activity of plant extract of Euphorbia nallamalayana against different pathogens. Four solvent extracts were evaluated for antimicrobial activity using well diffusion method and MIC determination on different micro organisms. The shade dried plant material was subjected to different solvents for phytochemical screening. The antibacterial activity was done using well diffusion method against eight potentially pathogenic microorganisms Aspergillus niger,Aspergillus flavus, Candida albicans, Saccharomyces cerevisiae, Escherchia coli , Staphylococcus aureus, Bacillus subtilus and Pseudomonas aeruginosa. Phytochemical screening was done using standard qualitative methods which revealed the presence of Tannins, Saponins, Steroids, coumarins, Flavones, Flavanones, Phenols, Quinones and Carbohydrates. There was no antifungal activity with Asperigillus flavus,Candida albicans and Saccharomyces cerevisiae. The findings of this study indicate that the plant extract of Euphorbia nallamalayana showed significant antibacterial activity against both gram positive and gram negative organisms. We also found the antifungal activity against Aspergillus niger. However, further studies on isolation characterization of plant extract responsible for antibacterial activity is necessary to elucidate their mechanism of action and it would give comprehensive evidence of bioactive potential of medicinal plants at cellular and molecular levels. Euphorbia nallamalayana has a strong antimicrobial potential, which justifies its use in folk medicine for treatment of infectious diseases. Since this species is poorly investigated, further refined studies on it pure secondary metabolites are needed and very important, in the perspective to identify new antimicrobial molecules from this endemic plant. 


\section{Introduction:-}

Medicinal plants are important source of therapeutic remedies of various ailments. Scientific experiments on the antimicrobial properties of plant components were documented in the late $19^{\text {th }}$ century [1]. The use of plants and plant product as medicines could be traced as far back as the beginning of human civilization. The earliest mention of medicinal use of plants in Hindu culture is found in "Rigveda', which is said to have been written between 4500-1600 BC. and is supposed to be the oldest repository of human knowledge. It is Ayurveda, the foundation of medicinal science of Hindu culture, in its eight division deals with specific properties of drugs and various aspects of science of life and the art of healing [2]. Plant derivatives, such as infusions and decoctions, have since long been used in traditional medicine for prevention and treatment of several pathologies [3,4]. Including common infectious diseases, leading causes of morbidity and mortality [5], which are directly responsible for $26 \%$ of annual deaths worldwide [6], were also treated by those plants preparations since ancient times [7]. In modern medicine, the discovery of bioactive molecules from microbial origin and synthetic antimicrobial agents decreased the use of traditional plant preparations, especially in developed countries. But in last decade, and besides their toxicities and side-effects [8], it has become clear that current antimicrobial drugs are losing their effectiveness [9], due to the emergence of resistance in pathogens to those antibiotics, which causes therapeutic failures and death of individuals [10]. Therefore, there is a continuing need to search for new antibiotics [5,9]. Since plant-derived antibacterial are always a source of novel therapeutics [11], many researchers in field of ethno-pharmacology have concentrated in studies of those compounds in the past few decades [7] on a promising and wealthy source for safe and effective new antimicrobial agents.Natural antimicrobials have been often derived from plants, microorganisms or animal tissues[12]. India is known for its rich diversity of medicinal world [13]. Nearly 70\% of world population is dependent on the traditional medicines for primary health care. The knowledge of medicinal plants has been accumulated during the course of many centuries based on different medicinal system such as Unani and Siddha[14]. Phytochemical from medicinal plants showing antimicrobial properties have the potential of filling this need, because their structure are different from those of more studied microbial sources, and therefore their mode of action may too very likely differ[15]. There is a growing interest in correlating the phytochemical constituents of a medicinal plant with its pharmacological activity [16]. An antimicrobial is a substance that kill microbes or prevent the growth of the plants with a new eye foe their antimicrobial usefulness and as an alternative source to the existing drug. Plants with their wide variety of chemical constituents offer a promising source of new antimicrobial agents as well as specific activity[17]. Phyto-chemical from medicinal plants sharing antimicrobial properties have the potential of filling this need, because their structure are different from those of more studied microbial sources, and therefore their mode of action may to vary likely differ[18]. Euphorbia linearifolia var.nallamalayana J.L.Ellis a synonym of Euphorbia deccanensis var. nallamalayana (J.L.Ellis) [19] belongs to the genus Euphorbiaceae family. In medicine, some species of Euphorbiaceae have proved effective against genital herpes [20,21].

There are several reports on the presence of antimicrobial compounds of various plants [22-26] but there are no reports on antimicrobial potential of Euphorbia nallamalyana which belongs to the family of Euphorbiaceae.

\section{Materials and methods:-}

The plant parts of Euphorbia nallamalayana were collected in and around Nallamala forest (Eastern Ghats) Pavuralagutta nearest to Nallakaluva village, Atmakur mandal of Kurnool district in Andhra Pradesh. The specimen was identified with the help of the regional floras [25-28] and the voucher specimen was deposited at Botanical Survey of India, Hyderabad.

\section{Preparation of Plant Extract :-}

The leaves and whole plant of Euphorbia nallamalayana were collected, shade dried, powdered and extracted with hexane, chloroform, methanol using soxhalet apparatus for 6hrs. The extracts were filtered and the filterate was concentrated under reduced pressure at $40^{\circ} \mathrm{C}$ using a rotaflash evapourater. The crude samples were subjected to antimicrobial screening against pathogenic organisms.

\section{Preparation of Standard culture inoculums of the test organism:-}

All the cultures were obtained from the Department of Microbiology, Andhra University, Visakhapatnam, A.P, India. From mother culture the inoculums was streaked and subcultured. Three or four isolated colonies were inoculated in $2 \mathrm{ml}$ nutrient broth and incubated for $24 \mathrm{hrs}$. The $24 \mathrm{hrs}$ cultured broth was used to check the antimicrobial activity.

Antibacterial Assay:- 
Antibacterial activity of extracts was determined by cup diffusion method on nutrient agar medium. Nutrient agar medium was prepared, sterilized and $0.2 \mathrm{ml}$ of $24 \mathrm{hrs}$ broth culture was mixed in the nutrient agar medium and poured in Petriplates. After solidifying wells are made in nutrient agar plates using cork borer [29].

Different concentrations of the working suspension of plant extracts and the same volume of the solvent for control were filled in the wells with micropipette. Plates were kept for some time until the extracts diffuse and incubated at $37^{\circ} \mathrm{C}$ for $24 \mathrm{hrs}$. After the incubation was completed, the plates were observed for zone of inhibition. The Minimum Inhibitory Concentration (MIC) was determined by the broth micro dilutions [30-31] using 96 well micro titer plates.

\section{Antifungal assay:-}

The antifungal properties with organic solvent (methanol, hexane and chloroform) extracts from the whole plants were investigated against pathogen. Potato dextrose agar medium was prepared allowed to cool and streptomycin sulphate was added to prevent bacterial contamination, and then was allowed to solidify. The fungal isolate was kept in the middle on the surface of the medium and the plant extracts were placed using disc diffusion method. All the plates were incubated at $27^{\circ} \mathrm{C}$ for $48 \mathrm{hrs}$. The zone of inhibition was measured along the control plates maintained by using available standard antifungal agents.

\section{Determination of Minimum Inhibitory Concentration (MIC) and Minimum Bactericidal Concentration (MBC):-}

Determination of the minimum inhibitory concentration (MIC) was carried out using the Broth dilution method [32] . Briefly, $1.0 \mathrm{ml}$ of the reconstituted Euphorbia nallamalayana extract solution at a concentration of $200 \mathrm{mg} / \mathrm{ml} \mathrm{was}$ added to another test tube containing $1 \mathrm{ml}$ of sterile broth so as to obtain a concentration of $100 \mathrm{mg} / \mathrm{ml}$. $1 \mathrm{ml}$ of this dilution was transferred to another test tube till the $7^{\text {th }}$ test tube was reached. The $8^{\text {th }}$ test tube did not contain any extract, but a solution of pure solvent and served as negative control. Then $1 \mathrm{ml}$ of an $18 \mathrm{~h}$ old culture of each of the bacteria earlier adjusted at $10^{8} \mathrm{cfu} / 1 \mathrm{ml}$ was put into each tube and thoroughly mixed on a vortex mixer. The tubes were incubated aerobically at $37{ }^{\circ} \mathrm{C}$ for $18-24 \mathrm{hrs}$. Two control tubes were maintained for each test batch. This is as follows: tube containing extracts and the growth medium without inoculums (antibiotic control) and the tube containing the growth medium, physiological saline and the inoculums (organism control). MIC was determined as the lowest concentration of the extracts permitting no visible growth (no turbidity) when compared with the control tubes. The MBC was determined by sub-culturing the test dilution on fresh solid medium and further incubated 37 ${ }^{0} \mathrm{C}$ at for $18-24 \mathrm{hrs}$. The $\mathrm{MBC}$ values were determined by removing $0.10 \mathrm{ml}$ of bacterial suspension from the MIC tubes that did not show any growth and subcultured into Muller Hinton agar plates and incubated at $37^{\circ} \mathrm{C}$ for $24 \mathrm{~h}$. After incubation, the concentration at which no visible growth was seen was recorded as the MBC. The lowest concentration of MIC tubes with no visible bacterial growth on solid medium was regarded as MBC.

\section{Identification Tests for Photochemical Constituents:-}

The tests were performed to find out the presence of active chemical constituents such as alkaloids, terpenes, flavones, flavonoids, steroids, reducing sugars, proteins, amino acids, carbohydrates, tannins, anthraquinones, glycosides, cardiac glycosides by the following procedure. Phytochemical analysis was carried out for all the extracts using standard methods [33-34].

\section{Alkaloids:-}

Extracts were dissolved individually in diluted hydrochloric acid. The resulting acidic solution was tested for alkaloids by adding Mayer's reagent, Wagner's reagent, Dragendroff reagent and Hager's reagent.

The formation of a faint turbidity or precipitation on the addition of the above reagents indicates the presence of alkaloids.

\section{Flavanoids:-}

$2-3 \mathrm{ml}$ of plant extract was dissolved in 50\% of methanol separately on sand bath with a piece of magnesium ribbon and $1 \mathrm{ml}$ of concentrated $\mathrm{Hcl}$ was added. Red or yellow coloration of the solution indicates the presence of flavanoids.

\section{Steroids:-}

$1 \mathrm{ml}$ of extract dissolved in $1 \mathrm{ml}$ of acetic anhydride, $1 \mathrm{ml}$ of chloroform and $1 \mathrm{ml}$ of conc. Hcl separately. Formation of green color indicates the presence of steroids. 


\section{Triterpenoids:-}

To $1 \mathrm{ml}$ of extract tin bit and thionyl chloride were added. Appearance pink color indicates the presence terpenoids.

\section{Coumarins:-}

To $1 \mathrm{ml}$ of plant extract, $1 \mathrm{ml}$ of $10 \% \mathrm{NaOH}$ was added. The presence of yellow color indicates the presence of coumarins.

\section{Cardiac glycosides:-}

To the plant extract few $\mathrm{ml}$ of glacial acetic acid, ferric chloride and conc. $\mathrm{H}_{2} \mathrm{SO}_{4}$ were added. Green color indicates the presence of cardiac glycosides.

\section{Terpenes:-}

To the plant extract few $\mathrm{ml}$ of chloroform was added, filtered. To the filterate few drops of acetic anhydride and $\mathrm{H}_{2} \mathrm{SO}_{4}$ were added. The color changing from blue to green indicates the presence of terpenes.

\section{Anthraquinones:-}

Benzene extract was taken to this $5 \mathrm{ml}$ of $10 \%$ ammonia was added .Pink, red or violet color indicates the presence of anthraquinones.

\section{Phlobtannins:-}

Plant extract was dissolved in distilled water. The filterate was boiled with $2 \% \mathrm{HCl}$. Red precipitate indicates the presence of phlobtannins.

Quinones:-

To $1 \mathrm{ml}$ of extract $1 \mathrm{ml}$ of conc. $\mathrm{H}_{2} \mathrm{SO}_{4}$ were added, formation of red color indicates the presence of quinones.

\section{Flavanones:-}

To few ml plant extract, $10 \%$ of few drops of $\mathrm{NaOH}$ was added yellow color indicates the presence of flavanones.

\section{Anthocyanins:-}

To the plant extract $10 \% \mathrm{NaOH}$ was added, blue color indicates the presence of anthocyanins.

\section{Proteins:-}

Biuret test:-

To few $\mathrm{ml}$ of plant extract, $1 \mathrm{ml}$ of $40 \% \mathrm{NaOH}$ solution and $2 \mathrm{ml}$ of $1 \% \mathrm{CuSO}_{4}$ were added. Violet color indicates the presence of proteins.

\section{Xanthoproetic test:-}

To few $\mathrm{ml}$ extract $1 \mathrm{ml}$ of conc. $\mathrm{HNO}_{3}$ was added. White precipitate was observed boiled and cooled. Then $20 \%$ of $\mathrm{NaOH}$ or $\mathrm{NH}_{3}$ was added. Presence of orange color indicates the presence of aromatic amino acid.

\section{Tannic acid:-}

To few ml of plant extract $10 \%$ of tannic acid was added. White precipitate indicates the presence of proteins.

\section{Carbohydrates:-}

Molisch's test:-

To few $\mathrm{ml}$ of plant extract $1 \mathrm{ml}$ of alpha-napthol solution and conc. $\mathrm{H}_{2} \mathrm{SO}_{4}$ was added along the walls of the test tube. Purple to reddish violet color at the junction of the two layers indicates the presence of carbohydrates.

\section{Fehling's test:-}

Equal volumes of fehling's - A \& B were added. On heating the formation of brick red precipitate indicates the presence of carbohydrates.

\section{Benedict's test:-}

To $5 \mathrm{ml}$ of Benedict's Reagent few $\mathrm{ml}$ of plant extract was added and boiled for $2 \mathrm{~min}$,cooled. The formation of red precipitate indicates the presence of carbohydrates. 
Aminoacids :-

2 drops of Ninhydrin Reagent was added to the plant extract. Purple color indicates the presence of aminoacids.

\section{Glycosides :-}

The extract was mixed with a little amount of Anthrone on watchglass and 1drop of conc. $\mathrm{H}_{2} \mathrm{SO}_{4}$ was added and made to fine paste and boiled gently on waterbath. Presence of glycosides shows dark green coloration.

\section{Results:-}

Phytochemical screening of whole plant and leaves extract of Euphorbia nallamalayana showed the presence of various bioactive compounds like alkaloids, tannins, saponins, steroids, terpenes, triterpenoids, phenols and carbohydrates.

The results of the present antimicrobial assay of different solvent extracts like methanol extract, chloroform extract and hexane indicated that the plant exhibited antimicrobial activity against different test microorganisms at four different concentrations of 50,100,250,500ug/ml.

The activity of the plant extract was obtained against all the five microorganisms were tested and the zone of inhibition was recorded and presented below in the tabulation drawn.

Table - 1 Phytochemical screening of different extracts of Euphorbia nallamalayana

\begin{tabular}{|c|l|c|c|c|c|}
\hline S.no & Phytoconstiuents & Methanol extract & Chloroform extract & Hexane extract & Aqueous extract \\
\hline 1 & Tannins & + & + & - & - \\
\hline 2 & Alkaloids & - & - & - & - \\
\hline 3 & Saponins & + & - & - & + \\
\hline 4 & Cardiac glycosides & - & + & - & - \\
\hline 5 & Steroids & + & - & - & - \\
\hline 6 & Terepenes & + & - & - & - \\
\hline 7 & Flavanoids & - & - & - & - \\
\hline 8 & Phlobtanins & - & - & - & - \\
\hline 9 & Anthraquinones & - & - & - & - \\
\hline 10 & Triterpenoid & - & + & + & + \\
\hline 11 & Coumarins & + & + & + & + \\
\hline 12 & Flavanones & + & - & - & - \\
\hline 13 & Flavones & + & - & - & - \\
\hline 14 & Anthocyanins & - & + & - & - \\
\hline 15 & Anthraquinones & - & - & - & - \\
\hline 16 & Phenols & + & - & - & - \\
\hline 17 & Quinones & + & - & - & - \\
\hline 18 & Glycosides & - & - & - & - \\
\hline 19 & Carbohydrates & - & - & - \\
\hline 20 & Amino acids & - & - & - \\
\hline 21 & Proteins & - & - & - \\
\hline
\end{tabular}

(+) -Present, (-) - Not Present

Table - 2 Antimicrobial activity of plant extract of Euphorbia nallamalayana

\begin{tabular}{|c|c|c|c|c|c|c|c|c|c|c|c|c|c|c|c|c|c|c|c|}
\hline \multirow{3}{*}{$\begin{array}{l}\text { S. } \\
\text { n } \\
\text { o }\end{array}$} & \multirow{3}{*}{$\begin{array}{l}\text { Name of } \\
\text { the } \\
\text { organis } \\
\text { m }\end{array}$} & \multicolumn{18}{|c|}{ ZONE OF INHIBITION (mm) } \\
\hline & & \multicolumn{4}{|c|}{$\begin{array}{l}\text { Methanol Extract } \\
\mathrm{mg} / \mathrm{ml}\end{array}$} & \multicolumn{4}{|c|}{$\begin{array}{l}\text { Hexane } \\
\text { Extract } \\
\mathrm{mg} / \mathrm{ml}\end{array}$} & \multicolumn{4}{|c|}{$\begin{array}{l}\text { Chloroform } \\
\text { Extract mg/ml }\end{array}$} & \multicolumn{4}{|c|}{$\begin{array}{l}\text { Aqueous Extract } \\
\mathrm{mg} / \mathrm{ml}\end{array}$} & \multicolumn{2}{|c|}{$\begin{array}{l}\text { Standard } \\
\text { Drugs }\end{array}$} \\
\hline & & 50 & 100 & $\begin{array}{l}25 \\
0\end{array}$ & $\begin{array}{l}50 \\
0\end{array}$ & $\begin{array}{l}5 \\
0\end{array}$ & $\begin{array}{l}1 \\
0 \\
0\end{array}$ & $\begin{array}{l}2 \\
5 \\
0\end{array}$ & $\begin{array}{l}50 \\
0\end{array}$ & $\begin{array}{l}5 \\
0\end{array}$ & $\begin{array}{l}1 \\
0 \\
0\end{array}$ & $\begin{array}{l}25 \\
0\end{array}$ & $\begin{array}{l}50 \\
0\end{array}$ & $\begin{array}{l}5 \\
0\end{array}$ & $\begin{array}{l}1 \\
0 \\
0\end{array}$ & $\begin{array}{l}25 \\
0\end{array}$ & 500 & $\begin{array}{c}\text { Anti } \\
\text { bacte } \\
\text { rial } \\
\text { Agen } \\
\text { t } \\
\text { Gent } \\
\text { amyc }\end{array}$ & $\begin{array}{l}\text { Antifun } \\
\text { gal } \\
\text { Agent } \\
\text { Gresiof } \\
\text { ulvin }\end{array}$ \\
\hline
\end{tabular}




\begin{tabular}{|c|c|c|c|c|c|c|c|c|c|c|c|c|c|c|c|c|c|c|c|}
\hline & & & & & & & & & & & & & & & & & & in & \\
\hline 1 & $\begin{array}{l}\text { Staphylo } \\
\text { coccus } \\
\text { aureus }\end{array}$ & 6 & 10 & 11 & 15 & - & - & - & - & - & - & 6 & 9 & 4 & 7 & 12 & 15 & 18 & - \\
\hline 2 & $\begin{array}{l}\text { Escheric } \\
\text { hia coli }\end{array}$ & 8 & 17 & 18 & 20 & - & - & 7 & 10 & - & 7 & 10 & 12 & 4 & 9 & 14 & 17 & 19 & - \\
\hline 3 & $\begin{array}{l}\text { Bacillus } \\
\text { subtilus }\end{array}$ & 7 & 10 & 14 & 17 & - & 5 & 8 & 12 & - & - & - & - & - & 8 & 8 & 10 & 19 & - \\
\hline 4 & $\begin{array}{l}\text { Pseudom } \\
\text { onas } \\
\text { aerugino } \\
\text { sa }\end{array}$ & 4 & 7 & 9 & 14 & - & - & - & - & 4 & 7 & 9 & 13 & - & - & 6 & 9 & 20 & - \\
\hline 5 & $\begin{array}{l}\text { Aspergill } \\
\text { us niger }\end{array}$ & 6 & 6 & 10 & 12 & - & - & 8 & 10 & - & - & 6 & 8 & - & 4 & 7 & 7 & - & 14 \\
\hline 6 & $\begin{array}{l}\text { Aspergill } \\
\text { us flavus }\end{array}$ & - & - & - & - & - & - & - & - & - & - & - & - & - & - & - & - & - & 18 \\
\hline 7 & $\begin{array}{l}\text { Candida } \\
\text { albicans }\end{array}$ & - & - & - & - & - & - & - & - & - & - & - & - & - & - & - & - & - & 16 \\
\hline 8 & $\begin{array}{l}\text { Saccharo } \\
\text { myces } \\
\text { cerevisia } \\
e\end{array}$ & - & - & - & - & - & - & - & - & - & - & - & - & - & - & - & - & - & 18 \\
\hline
\end{tabular}

Table - 3 Minimum Inhibitory Concentration of plant extract of Euphorbia nallamalayana

\begin{tabular}{|c|c|c|c|c|c|c|c|c|c|c|c|}
\hline \multirow{3}{*}{$\begin{array}{l}\text { S.n } \\
\text { o }\end{array}$} & \multirow{3}{*}{$\begin{array}{c}\text { NAME OF } \\
\text { THE } \\
\text { ORGANIS } \\
\text { M }\end{array}$} & \multicolumn{10}{|c|}{ Minimum Inhibitory Concentration mg/ml } \\
\hline & & \multicolumn{2}{|c|}{$\begin{array}{l}\text { Methanol Extract } \\
\mathrm{mg} / \mathrm{ml}\end{array}$} & \multicolumn{2}{|c|}{$\begin{array}{l}\text { Hexane Extract } \\
\mathrm{mg} / \mathrm{ml}\end{array}$} & \multicolumn{2}{|c|}{$\begin{array}{l}\text { Chloroform } \\
\text { Extract } \mathrm{mg} / \mathrm{ml}\end{array}$} & \multicolumn{2}{|c|}{$\begin{array}{l}\text { Aqueous Extract } \\
\mathrm{mg} / \mathrm{ml}\end{array}$} & \multicolumn{2}{|c|}{ Gentamycin } \\
\hline & & MIC & $\begin{array}{l}\mathrm{MB} \\
\mathrm{C}\end{array}$ & MIC & $\begin{array}{l}\mathrm{MB} \\
\mathrm{C}\end{array}$ & MIC & $\begin{array}{l}\mathrm{MB} \\
\mathrm{C}\end{array}$ & MIC & $\begin{array}{l}\mathrm{MB} \\
\mathrm{C}\end{array}$ & MIC & $\begin{array}{l}\mathrm{MB} \\
\mathrm{C}\end{array}$ \\
\hline 1 & $\begin{array}{l}\text { Staphyloco } \\
\text { ccus } \\
\text { aureus }\end{array}$ & $\begin{array}{l}0.032 \pm 0 . \\
000\end{array}$ & $\begin{array}{l}0.02 \\
5\end{array}$ & ND & ND & $\begin{array}{c}0.063 \pm 0 . \\
000\end{array}$ & $\begin{array}{l}0.1 \\
00\end{array}$ & $\begin{array}{l}1.000 \pm 0 . \\
000\end{array}$ & $\begin{array}{l}0.03 \\
45\end{array}$ & $\begin{array}{l}2.000 \pm 0 . \\
000\end{array}$ & $\begin{array}{c}0.04 \\
7-\end{array}$ \\
\hline 2 & $\begin{array}{l}\text { Escherichi } \\
\text { a coli }\end{array}$ & $\begin{array}{l}0.020 \pm 0 . \\
000\end{array}$ & $\begin{array}{l}0.50 \\
0\end{array}$ & $\begin{array}{l}4.000 \pm 0 . \\
000\end{array}$ & $\begin{array}{l}0.1 \\
25\end{array}$ & $\begin{array}{l}1.000 \pm 0 . \\
000\end{array}$ & - & $\begin{array}{l}0.040 \pm 0 . \\
000\end{array}$ & $\begin{array}{l}\geq 100 \\
0\end{array}$ & $\begin{array}{l}0.015 \pm 0 . \\
014\end{array}$ & $\begin{array}{c}0.01 \\
8-\end{array}$ \\
\hline 3 & $\begin{array}{l}\text { Bacillus } \\
\text { subtilus }\end{array}$ & $\begin{array}{c}0.125 \pm 0 . \\
000\end{array}$ & $\begin{array}{l}0.02 \\
50\end{array}$ & ND & ND & ND & ND & $\begin{array}{l}0.250 \pm 0 . \\
000\end{array}$ & $\begin{array}{l}0.06 \\
3\end{array}$ & $\begin{array}{l}4.000 \pm 0 . \\
000\end{array}$ & $\begin{array}{c}012 \\
5\end{array}$ \\
\hline 4 & $\begin{array}{l}\text { Pseudomon } \\
\text { as } \\
\text { aeruginosa }\end{array}$ & ND & $\begin{array}{l}\geq 100 \\
0\end{array}$ & ND & ND & ND & ND & ND & ND & $\begin{array}{l}1.000 \pm 0 . \\
000\end{array}$ & $\begin{array}{c}0.10 \\
0 \\
\end{array}$ \\
\hline
\end{tabular}

ND: not detected

\section{Discussion:-}

In the present investigation, the active phyto components of Euphorbia nallamalayana was studied and further the antimicrobial activity of the plant extract was also tested against eight potentially pathogenic microorganisms Aspergillus niger, Aspergillus flavus, Candida albicans, Saccharomyces cerevisiae , Escherchia coli , Staphylococcus aureus, Bacillus subtilus and Pseudomonas aeruginosa at different concentrations of the extract to understand the most effective activity.

Among the four solvent extracts methanol extract was more effective on test pathogens when compared to that of hexane, chloroform and Aqueous. Methanol extract showed significant inhibition zone ranging from 6-20mm against all the microorganisms. In the present study Escherchia coli, Bacillus subtilus were proved to be more susceptible at different concentrations of the plant extract. Among the fungal strains Asperigillus niger was susceptible to methanol extract and showed zone of inhibition ranging from $6-12 \mathrm{~mm}$ at different concentrations. The 
MBC was observed to be more when compared with that of MIC in Staphylococcus aureus, Bacillus subtilus and Escherchia coli in methanol extract.

In the present study, antibiotic potential of leaf extracts of Euphorbia nallamalayana plants has been determined against eight pathogens named Aspergillus niger, Aspergillus flavus, Candida albicans, Saccharomyces cerevisiae, Escherchia coli, Staphylococcus aureus, Bacillus subtilus and Pseudomonas aeruginosa. For the comparison positive and negative controls were used. Negative controls did not show inhibitory action on any of the test organisms, while positive controls significantly inhibited growth of all eight test organisms. The findings match with that of other findings [35-36]. It is often reported that Gram positive bacteria are more sensitive than Gram negative bacteria to plant based organic extracts [37-39]. But in our study, both gram positive and gram negative bacteria were found to be sensitive to plant extracts. In present study, Staphlococcus aureus was found to be most sensitive while Aspergillus flavus, Candida albicans and Saccharomyces cerevisiae were found to be least sensitive to plant organic extract than other organisms. The findings agree with that of other similar findings [40] .The antibacterial properties of medicinal plants may be due to presence of different chemical agents which were classified as bioactive antimicrobial compounds [41]. Phytochemical constituents such as alkaloids, glycosides, flavonoids, tannins, steroids, terpenoids and several other compounds are secondary metabolites of plants that serve as a defense mechanism against many microorganisms, insects and other herbivores. The present study also revealed the presence of medicinally active compounds like alkaloids, glycosides, flavonoids, steroid, terpenoid and tannins in most of the selected plants which could be responsible for the observed antibacterial property.

\section{Conclusion:-}

The plant extract of Euphorbia nallamalayana showed significant antibacterial activity against both gram positive and gram negative organisms. However further studies on isolation characterization of chemical constituents of the plant extract responsible for antibacterial activity is necessary to elucidate their mechanism of action and it would give comprehensive evidence of bioactive potential of medicinal plants at cellular and molecular levels.

\section{Acknowledgements:}

The authors acknowledge their profound gratitude to UGC-BSR-SAP for financial assistance to carry out the study. The authors wish to acknowledge Dr. A.Veerabhadra Rao, Centre for Cellular and Molecular Biology, Hyderabad for providing facilities for research work. We are highly indebted to Dr. B. Suresh and Dr. Zehera, Indian Institute of Chemical Technology, for their valuable suggestions.

\section{References:-}

1. Zaika L.L. (1975): Species and herbs their antimicrobial activity 9:97-118.

2. Rastogi RP, Mehrotra BN (2002): Glossary of Indian medicinal plants. National Institute of Science Comunication, New Delhi, India.

3. Gonçalves S, Gomes D, Costa P, Romano A. (2013): The phenolic content and antioxidant activity of infusions from Mediterranean medicinal plants. Ind Crops Prod; 43(1): 465-471.

4. Luo H, Li Q, Flower A, Lewith G, Liu J. (2012): Comparison of effectiveness and safety between granules and decoction of Chinese herbal medicine: A systematic review of randomized clinical trials. J Ethno pharmacol 140(3): 555-567.

5. Radulovic NS, Blagojevic PD, Stojanovic-Radic ZZ, Stojanovic NM. (2013): Antimicrobial plant metabolites: Structural diversity and mechanism of action. Curr Med Chem 20(7): 932-952.

6. Morens DM, Folkers GK, Fauci AS. (2008): Emerging infections: a perpetual challenge. Lancet Infect Dis 8(11): 710-719.

7. Ríos JL, Recio MC. ( 2005): Medicinal plants and antimicrobial activity. J Ethno pharmacol 100(1-2): 80-84.

8. Grill MF, Maganti RK. (2011): Neurotoxic effects associated with antibiotic use: management considerations. Br J Clin Pharmacol 72(3): 381-393.

9. Saleem M, Nazir M, Ali MS, Hussain H, Lee YS, Riaz N, (2010): Antimicrobial natural products: an update on future antibiotic drug candidates. Nat Prod Rep 27(2): 238-254.

10. Hooper DC, DeMaria A, Limbago BM, O’Brien TF, McCaughey B. (2012):Antibiotic resistance: how serious is the problem, and what can be done? Clin Chem 58(8): 1182-1186.

11. Hemaiswarya S, Kruthiventi AK, Doble M. (2008): Synergism between natural products and antibiotics against infectious diseases. Phytomedicine 15(8): 639-652.

12. Gordon M.C and David J.N. (2001):Natural product drug discovery in the next millennium. Pharm Biol. 139:8-17

13. Vedavathy S, Mrudula V and Sudhakar A Tribal in Chitoor District, Andhra Pradesh, India. Vedams e book P,Ltd 1977. 
14. Pei,S.J.(2001): Ethanobotanical approaches of traditional medicine studies: Some experiences from Asia. Pharmaceutical biology 39:74-79.

15. Fabricant D.S and Fansworth N.R. (2001): The value of plant used in traditional medicine for drug discovery. Environ. Health Perspect. 109:69-79.

16. Al-Bayati F.A and Al-Mola H.F. (2008): Antibacterial and antifungal activity of different parts of Tribulus terrestris L growing in Iraq: J. Zhejiang Univ. Sci. B. 9:154-159.

17. Evans W.C. Trease and Evans (1996): pharmacognosy $14^{\text {th }}$ Edition. WB Sacender Company Ltd., pp.290.

18. Fabricant D.S and Fansworth N.R. (2001): The value of plants used in traditional medicine for drug discovery. Environ. Health Perspect. 109;69-79.

19. http://www.theplantlist.org/tpl1.1/record/kew-80596.

20. Ahmed,Z.U.Begum,Z.N.T.,Hassan,M.a.Khonder,M.,Kabir,S.M.H.,Ahmad,M.,Ahmed,A.T.A.Rahman,A.K.A,Haque, E.U.(Eds). Encyclopedia of Flora and Fauna of Bangladesh Dicotyledons. Asiat. Soc. Bangladesh, Dhaka, 20072009, Vol 6-12,

21. Charles, C. D., Maribeth, L., Daniel, L. N., Kenneth, J. W., David, A. B. Floral Gigantism in Rafflesiaceae Science Express ,USA.2007.

22. Ravindra, B., Malabadi, Gangadhar, S., Mulgund and Nataraja, K. (2005):Screening an antibacterial activity in the extracts of Clitorea ternatea, Jour medical and Aromatic Plant Sciences, 27,26-29.

23. Prusti,A., Misra,S.R.,Sahoo,S. and Mishra,S.K., (2008):Antibacterial activity of some Indian medicinal plants, Ethnobotanical leaflets, 12,227-230.

24. Nair, R., Kalariya, T., Sumitra chanda., (2005): Antibacterial activity of some selected Indian medicinal flora. Turk J Biol, 29,41-47.

25. Ahmad, I., Mehmood, Z and Mehmood, I., (1998): Screening of some Indian medicinal plants for their antimicrobial properties. J Ethnopharmacol, 62,183-193.

26. Arjuna Patra, Jha,S., Murthy,P.N. Satpathy, S., Antibacterial activity of Hygrophila Spinosa T.Andres (2009): leaves. A comparative study. Int J Pharm Tech Res, 1(3), 837-839.

27. Pullaiah T \& Ali. Moulali D. (1977): Flora of Andhra Pradesh, $1^{\text {st }}$ ed ,Vol - II,Jodhpur ;Scientific Publishers.

28. Ellis JL. (1987): Flora of Nallamalais ,Vol -II Botanical Survey of India.

29. Anonymous, (1996) The Indian pharmacopoeia Government of India, New Delhi. Ministry of Health and family welfare;

30. National Committee for Clinical Laboratory Standards. Performance Standards for Anti-Microbial Susceptibility Testing: Eleventh International Suppliment. NCCLS,2001, M100-S11.

31. Amarsingham P.P, Bisset, N.G, Millard P.H, Woods M.C, (1964): Phytochemical Survey of Malaya part 3.Alkaloids and Saponins. Economic Taxonomic Botany 18:270-278.

32. Sahm DF, Washington JA (1990). Antibacterial susceptibility tests: Dilution methods. In: Manual of clinical Microbiology. Lennette, EH (ed.), 5th edition. American Society of Microbiology, Washington, DC. pp. 1105-1118.

33. Harborne, J.B,. Phytochemical methods: A guide to modern techniques of plant analysis Champman \& Hall, London 973,279.

34. Raaman N. (2006) Phytochemical Techniques . New India Publishing Agency.New Delhi.

35. Rahman, A., Parvez, M.A.K., Parvin, T., Paul, D.K., Sattar, M.A., (2004): Antimicrobial activity of three bioactive compounds from the stream bark of Piper chaba hunter. Bioscie. Res., 1: 1620.

36. Bhattacharjee, I., Chatterjee, S.K., Chatterjee, S., Chandra, G. (2006): Antibacterial potentiality of Argemone mexicana solvent extracts against some pathogenic bacteria. Memorias do Instituto Oswaldo Cruz., 101: 645648.

37. Reynolds, J.E.F. Martindale (1996): the extra harmacopoeia, 31st edn, Royal Pharmaceutical Society of Great Britain, London.

38. Bezic, N.M., Dinkic, S.V., Radonic, (2003): A., Composition and antimicrobial activity of Achillea clavennae L. essential oil. Phytother. Res., 17: 10371040.

39. Rahman, M.M., Alam, J., Sharmin, S.A., Rahman, A., Alam, M.F. (2009): In Vitro antibacterial activity of Argemone mexicana L. (Papaveraceae). CMU J. Nat. Sci., 8: 7784.

40. Joshi, B., Sah, G.P., Basnet, B.B., Bhatt, M., Sharma, D., Subedi, K., Pandey, J., Malla, R., (2011): Phytochemical extraction and antimicrobial properties of different medicinal plants: Ocimum sanctum (Tulsi), Eugenia caryophyllata (Clove), Achyranthes bidentata (Datiwan) and Azadirachta indica (Neem). J. Microbiol. Antimicrob., 3(1): 17.

41. Arulmozhi, S., Mazumder, P.M., Ashok, P., Narayanan, L.S., (2007):Pharmacological activities of Alstonia scholaris Linn. (Apocynaceae)- A review. Pharmaco. Rev., 1: 163165. 